World Bank Conference on Bank Privatization

Washington, D.C., November 20-21, 2003.

Revised March 2004

\title{
Privatization Matters: Bank Efficiency in Transition Countries
}

\author{
John P. Bonin, \\ Department of Economics \\ Wesleyan University, Middletown, CT 06459 \\ jbonin@,wesleyan.edu \\ 8606852353 \\ Iftekhar Hasan, \\ Rensselaer Polytechnic Institute, Troy, NY \\ hasan@rpi.edu \\ 5182762525 \\ Paul Wachtel, \\ Stern School of Business \\ New York University, New York, NY 10012 \\ pwachtel@stern.nyu.edu \\ 2129984030
}

The authors express their appreciation to Robert Cull and George Clarke of the World Bank for inviting our participation in the bank privatization project and for invaluable advice and support. The discussants at the conference, Istvan Abel and Luc Laeven, made many useful suggestions and comments. Moisa Altar, Bozena Leven, Laszlo Szakadat and Assenka Yonkova provided information on the banks in the countries studied. We thank Elif Sisli, Liang Zhao, and Minyuan Zhao for able research assistance. 


\title{
Privatization Matters: Bank Efficiency in Transition Countries
}

\author{
John Bonin, Iftekhar Hasan and Paul Wachtel
}

\begin{abstract}
To investigate the impact of bank privatization in transition countries, we take the largest banks in six relatively advanced countries, namely, Bulgaria, the Czech Republic, Croatia, Hungary, Poland and Romania. Income and balance sheet characteristics are compared across four bank ownership types. Efficiency measures are computed from stochastic frontiers and used in ownership and privatization regressions having dummy variables for bank type. Our empirical results support the hypotheses that foreign-owned banks are most efficient and government-owned banks are least efficient. In addition, the importance of attracting a strategic foreign owner in the privatization process is confirmed. However, counter to the conjecture that foreign banks cream skim, we find that domestic banks have a local advantage in pursuing fee-for-service business. Finally, we show that both the method and the timing of privatization matter to efficiency; specifically, voucher privatization does not lead to increased efficiency and earlyprivatized banks are more efficient than later-privatized banks even though we find no evidence of a selection effect.
\end{abstract}

JEL Classifications: P30, P34, and P52 


\section{Introduction}

Banking sectors in the transition economies of Central and Southeastern Europe were restructured dramatically the 1990s. Beginning with a financial organization that, in most cases, was designed to support the central planning apparatus, new governments moved to create modern commercial banking sectors immediately. The first rudimentary step was to divest commercial and retail activities from the portfolios of national banks and to set up new joint-stock banks with universal licenses that were fully state-owned initially. Bank privatization was an essential part of the financial reform agendas in these countries. Although much descriptive work exists on these financial sector reforms and bank privatizations, e.g., Bonin, Mizsei, Székely, and Wachtel (1998), no systematic empirical work was possible until sufficient time had elapsed to make the construction of a meaningful dataset possible. The basic issue to investigate is whether or not privatization improves bank performance. Although the theoretical literature indicates that private firms should outperform government-owned firms, empirical evidence is needed to confirm this theoretical hypothesis for banks in transition countries.

The empirical literature provides evidence of the influence of ownership on the performance of individual banks and on the effectiveness of the banking sector. In a cross-country study, La Porta, Lopez-De-Silanes, and Shleifer (2002) find that the performance of government-owned banks is inferior to that of private banks. Claessens, Demirgüc-Kunt and Huizinga (2001) investigate performance differences between domestic and foreign banks in eighty countries, both developed and developing, over an eight-year period from 1988 to 1995 . These authors find that foreign bank entry was followed by a reduction in both the profitability and the overhead expenses of domestic 
banks and that foreign banks in developing countries perform better than do domestic banks. For Latin American countries, Crystal, Dages, and Goldberg (2001) argue that foreign bank entry is associated with improved production of financial services and more banking competition; in addition, they claim that it facilitates the early waves of privatization of government-owned domestic banks. Hence, this empirical literature provides evidence that ownership matters; in particular, government ownership of banks is less efficient than private ownership and foreign bank entry has a salutary effect on banking sectors.

Much of the empirical literature on banking in transition countries addresses the impact of foreign bank entry on banking efficiency. Hasan and Marton (2003), Drakos (2003), and Fries and Taci (2003) demonstrate that the entry of more efficient foreign banks creates an environment that forces the entire banking system to become more efficient, both directly and indirectly, in transition countries. Buch (2000) compares interest rate spreads in the three fast-track transition countries, Hungary, Poland and the Czech Republic, from 1995 to 1999 . She finds evidence confirming the hypothesis that foreign banks create a more competitive market environment in transition economies, but only after they have attained sufficient aggregate market share. A few studies examine the effects of ownership on individual bank efficiency. For Poland, Nikiel and Opiela (2002) find that foreign banks servicing foreign and business customers are more costefficient but less profit-efficient than other banks in Poland. Bonin, Hasan, and Wachtel (2003) examine the performance of banks in eleven transition countries and show that majority foreign ownership is associated with improved bank efficiency. However, these 
authors cannot investigate privatization directly because their data do not distinguish among different types of foreign bank ownership.

Studies focusing specifically on the effects of bank privatization are less numerous. Verbrugge, Megginson and Owens (2000) document marginal performance improvements and increases in equity among privatized banks in OECD countries. For Argentina, Clark and Cull $(1999,2000)$ study the privatization process and show that the success of the provincial bank privatization depended on the effectiveness of the buyers. These authors find evidence that credit allocation and efficiency are higher in privatized banks. The transformation of the Argentine banking system occurred mainly through domestic mergers and acquisitions so that foreign banks played only a relatively minor role. In the transition countries, the prevalence of foreign strategic owners in formerly state-owned but subsequently privatized banks makes it crucial to distinguish these banks from foreign greenfield banks when analyzing bank privatization.

In this paper, we focus on six relatively advanced transition countries, namely, Bulgaria, the Czech Republic, Croatia, Hungary, Poland and Romania. We chose not to include banks in very small transition economies, e.g., the Baltic countries and Slovenia, and those in less advanced transition economies that have only recently restructured the banking system, e.g., the former Soviet Union, Albania and the other Balkan states. In the next section, we present a brief description of the privatization experiences in these six countries to establish that the strategies and the timing of privatizations are sufficiently different to allow us to use these experiences as the basis for an empirical analysis of privatization. Section 3 describes our dataset and presents the results of testing for differences in means across bank types for several measures of bank 
performance and for several bank characteristics. Section 4 characterizes briefly our methodology of deriving profit and cost efficiency measures from stochastic frontier estimates that allow for country and year effects directly in a pooled data set. In this section, we relate the bank efficiency scores, as well as a measure of financial performance, to the type of ownership and the method of privatization in second-stage regressions. Section 5 concludes with a brief summary focusing on policy implications.

\section{Bank Privatization in Six Transition Economies}

Pre-transition banking sectors were designed to meet the needs of a centrally planned economy (CPE). Intermediation between savers and borrowers was internalized within the state banking apparatus basically through a system of directed credits to stateowned enterprises for both investment needs and budget allocations for the working capital necessary to meet the output plan. In most CPEs, large specialty banks performed specific functions. A state savings bank, with an extensive branch network, collected virtually all household deposits. A foreign trade bank handled all transactions involving foreign currency. An agricultural bank provided short-term financing to the agricultural sector. A construction bank funded long-term capital projects and infrastructure

development. Hence, banking activities were both subservient to the plan and segmented along functional lines in CPEs.

In the transition economies (TEs), the first step in banking sector reform involved creating a two-tier system with commercial banking activities carved out of the old central bank. At the beginning of the decade, the new banking sectors in the former CPEs consisted of the newly created commercial banks and the specialty banks, both types 
having universal banking licenses, along with a few foreign greenfield banks and often many relatively undercapitalized de novo domestic private banks that were born under lax entry requirements. Specialty banks had virtual monopolies in their core activities, e.g., the savings bank was often the only entity with an extensive enough branch network throughout the country to collect primary deposits. Typically, three or four large banks dominated the emerging banking sector in a TE. Both the newly created commercial entities and the specialty banks were state-owned initially. Hence, structural segmentation, a proliferation of weak small domestic private banks, and state-ownership of the large banks were the major features of banking sectors in TEs at the beginning of the 1990s.

These legacies affected the banking sectors in all of the countries in our sample with the exception of Croatia, which was part of Yugoslavia. From the 1950s, commercial banks in Croatia as well as the other republics were not state-owned but were owned collectively according to the Yugoslavian system of self-management. Virtually all foreign exchange deposits collected by the republic-level banks were remitted to the National Bank of Yugoslavia in Belgrade in exchange for credits in dinars. Upon succession in June 1991, the Yugoslavian government froze the foreign exchange deposits of Croatian banks. Hence, Croatian banks faced a currency mismatch between assets and liabilities creating large holes in their balance sheets after succession. At the end of 1995, four Croatian banks were selected for government rehabilitation because of the poor quality of their loan portfolios. Involvement in this program resulted in these banks being nationalized so that four large state-owned banks were created in Croatia in the middle of the 1990s. 
The three more advanced TEs, i.e., Czech Republic, Hungary, and Poland, embarked on significantly different bank privatizations programs during the first half of the 1990s. Even before the political change, the Hungarian government had been receptive to foreign bank activity as it allowed three foreign banks to operate in the country from 1985. By the end of 1994, the Hungarian foreign trade bank had been purchased by a foreign owner and foreign investors held about $20 \%$ of total banking assets in Hungary. In the Czech Republic, three of the largest four banks participated in the first wave of voucher privatization in 1992. Investment funds, the largest of which were created by these banks, were an integral part of the Czech voucher privatization program. Hence, this initial divestiture of state holdings resulted in interlocking ownership with the state retaining large controlling stakes of voucher-privatized Czech banks. At the end of 1994, although foreign investors held about 6\% of banking assets in the Czech Republic, none of the large banks had any foreign ownership. With some inducement from the G7 donor countries and international financial institutions, Polish authorities set a three-year timetable at the beginning of 1993 for privatizing the nine medium-sized, regional, stateowned banks that were created from the commercial portfolio of the national bank. However, by the end of 1994, only two of these banks had been privatized and only two more would be privatized before 1997. Foreign ownership of banking assets remained insignificant in Poland at about 2\% in the mid-1990s.

Macroeconomic instability and financial sector distress made bank privatization infeasible in Bulgaria and Romania during the first half of the 1990s. By 1995, neither Bulgaria nor Romania had privatized any banks and foreign ownership of banking assets was negligible at less than $1 \%$ in both countries. In Croatia, only one small foreign bank 
was operating in 1995 and there was hardly any foreign ownership of banking assets. Of the six countries, only Hungary and to a lesser extent Poland had committed to selling banks to foreign investors by the end of the first half of the 1990s. However, by the end the decade, five of the six countries were embarked on, or had completed, privatizations that would put at least 75\% of their banking assets under foreign control by 2002 .

The second half of the 1990s witnessed a flurry of bank privatizations in these countries. Appendix A lists the banks in our sample from each country ranked according to market share at the end of the decade. Information on each bank's status throughout the 1990s is provided and, when relevant, the bank's privatization is dated. Bank privatization proceeded relatively swiftly in Hungary; by mid-1997, eight of the top ten banks were majority foreign-owned. After a few initial bank privatizations, the Polish government became sidetracked by a bank consolidation initiative that was intended to fend off foreign competition. Nonetheless, a combination of mergers and privatizations involving foreign partners left foreigner investors holding more than $75 \%$ of Polish banking assets by 2000 . Although the Czech government was late to recognize the importance of attracting strategic foreign investors for its large voucher-privatized banks, all major banks were sold to foreign owners by mid- 2001 .

Both of the southeastern TEs, i.e., Bulgaria and Romania, began bank privatization only in the late 1990s. After instituting a currency board and stabilizing the macroeconomic environment, the Bulgarian government privatized its first bank to a consortium of investors in 1997. By the end of 2000, eight of the ten largest banks in Bulgaria were foreign owned. Romania is a laggard in bank privatization compared to the other former CPEs. In 2000, foreign investors owned less than half of Romanian banking 
assets and two of the three largest banks remained state-owned as late as 2003 .

Beginning in 1995 with virtually no holdings in Croatia, foreigner investors had acquired about $84 \%$ of banking assets by 2000 and, by 2002 , all of the ten largest banks in the country were majority foreign owned.

In summary, Hungary was the first country to shed the legacies of the CPE by privatizing all but one of its major banks by mid-1997. In Poland, after some delay in the privatization timetable, only the zloty savings bank and the umbrella agricultural bank remain state-controlled. Initially, the Czech Republic placed three big banks in the voucher privatization program but, despite a late start, foreign investors gained control of all large Czech banks by mid-2001. The banking sectors in Bulgaria, Romania, and Croatia were financially distressed in the first half of the 1990s, albeit for different reasons, so that bank privatization could not begin until the late 1990s. Once started, sales of banks to foreign investors were rapid in Bulgaria and Croatia. Romania is the only one of the six transition countries in this study to retain significant government ownership in its banking sector through 2003 with only one of its three largest banks privatized.

\section{The Data and Bank Characteristics by Type}

The dataset consists of the largest banks by asset size in the six selected countries. As is shown in Appendix A, the smallest bank in the sample has a market share ranging between 2\% in the Czech Republic and 4\% in Poland. Taken together, the large banks in 
our sample hold more than $75 \%$ of the banking assets in their respective countries. ${ }^{1}$

Restricting the sample to large banks yields a more homogeneous set of observations than is often found in other studies of banking in transition countries. Homogeneity is important for investigating the effects of privatization on individual banks because privatized state-owned banks are usually among the largest banks in their respective countries. Moreover, our sample contains a sufficient number of large banks of various types to make comparisons meaningful.

Balance sheet and income data are taken from Thompson's BankScope and Bureau van Dijk. Data for each bank was examined to insure that all available relevant information was used. Thus, we took care to avoid duplicating data for the same bank when alternative accounting standards or different levels of consolidation are reported in BankScope. The total number of bank observations is 451; a bank observation is datum for an individual bank in a particular year. We have information for 67 different banks from 1994 to 2002, although data are not available for every year for every bank. ${ }^{2}$ Most of the observations are for 1995 to 2001 as Table 1 indicates. In terms of country coverage, Romania has the fewest observations accounting for $9.1 \%$ of the total while Poland has the most at $25.5 \% .^{3}$

To facilitate our investigation of privatization, we divide the observations into four mutually exclusive bank types, namely foreign greenfield, domestic de novo, state owned, and privatized. As reported in Table 1, foreign greenfield banks constitute almost

\footnotetext{
${ }^{1}$ There are not exactly ten banks for several countries because of data limitations. Moreover, by the end of the 1990s, some of the large banks in several of the countries are the result of mergers and acquisitions; whenever possible, we included the precursor organizations in our dataset.

${ }^{2}$ No data were available for three foreign banks listed in Appendix A because their balance sheets were consolidated with their parent banks.

3 The large proportion of bank observations from Poland reflects the mergers and acquisitions that took place in that country in the late 1990s; when data are available we include observations for the major predecessor banks.
} 
a quarter of all bank observations, which indicates the importance of foreign penetration into the banking sectors of these six transition countries. Domestic de novo banks make up the smallest category because only a few of the domestic entrants in the early 1990s grew to become one of the ten largest banks in its country by the end of the decade. About $10 \%$ of the total, or about $38 \%$ of the observations in the state-owned category, are banks that were not privatized during our sample period. ${ }^{4}$ The majority of the observations in the state-owned category represent the pre-privatization histories of banks that were privatized within the sample time period. Adding the post-privatization experiences of both these banks and those banks that were privatized throughout the sample period to these pre-privatization histories encompasses almost half of all bank observations in our sample. ${ }^{5}$

Privatization is concentrated in the post-1997 period as Table 1 indicates. The three years prior to 1997 account for less than $20 \%$ of the observations for privatized banks. ${ }^{6}$ In contrast, about $79 \%$ of all privatized observations come from the years between 1997 and 2001. ${ }^{7}$ Table 1 contains additional information about the privatization process. The column labeled strategic owner indicates that a strategic foreign investor has a majority-controlling stake in a privatized bank or, in a few cases, in a domestic de novo bank. By definition, foreign greenfield banks are controlled by a strategic foreign owner but these banks are not included in this column. Almost one fourth of all the bank

\footnotetext{
${ }^{4}$ Six large banks, two in Bulgaria (DSK and Biochim), two in Poland (PKO and BGZ), and two in Romania (BCR and CEC), account for these observations as Appendix A indicates.

${ }^{5}$ Eight banks in the data set were privatized throughout the time period. These are the three voucherprivatized Czech banks (KB, CS, and IPB), two banks in Hungary (MKB and General Banking Trust), and three banks in Poland (BRE, BSK, and WBK). For these banks, we have no pre-privatization histories.

${ }^{6}$ In addition to the eight banks already identified, two banks in Hungary (OTP in 1995 and BB in 1996) and two banks in Poland (BPH in 1995 and BG in 1996) are privatized prior to 1997.

${ }^{7}$ Only limited data were available for 2002 when the data set was constructed; there are 9 observations of which 4 are for privatized banks.
} 
observations are foreign greenfield operations and almost the same fraction is domestic banks with a strategic foreign investor. In about $74 \%$ of all privatized observations, the bank has a strategic foreign owner. Across countries, the percentage of privatized observations having a strategic foreign owner ranges from $43 \%$ in the Czech Republic, mainly due to voucher privatization, and $50 \%$ in Romania, due to its late start on bank privatization, to $72 \%$ in Hungary and more than $80 \%$ in Bulgaria, Croatia, and Poland.

To investigate whether bank privatization matters, we report the means for various performance measures and characteristics by bank type in Table 2. With the exception of assets, all means are adjusted to remove country and year fixed effects. ${ }^{8}$ The means are shown for each of the four ownership categories and for the whole sample. In addition, the last two columns show the means for the pre-privatization histories and the post-privatization experiences of the banks privatized in our sample period. Table 3 contains signed t-statistics for tests comparing the means between privatized banks and each other bank type as well as between post-privatization histories and pre-privatization experiences. A positive (negative) sign on a t-statistic indicates that privatized banks have a higher (lower) mean for that measure than do banks in the comparison category. Statistical significance at the $5 \%$ or better level is represented by a bold t-statistic in Table 3.

Taking bank characteristics first, privatized banks are the largest of the four classes and foreign greenfield banks are the smallest at about half the average size of domestic de novo banks. To some extent, the difference in the mean asset size of stateowned and privatized banks reflects the timing of privatization. The first and last

\footnotetext{
${ }^{8}$ The adjustment is made by regressing the particular bank characteristic on dummy variables for countries and years. The adjusted value is the regression residual plus the overall mean; hence, it has the country and year effects removed.
} 
columns of Table 3 present the effects of the bank privatization process. Prior to privatization, banks are recapitalized and their balance sheets are cleaned of some bad loans. Reflecting this preparation, the equity ratio increases significantly and becomes comparable that of foreign greenfield banks in privatized banks. However, privatization is not associated with a significant decrease in loan loss provisioning or liquid asset holding. Relative to foreign greenfield banks, privatized banks have higher liquid asset and loan loss provision ratios. The high liquid asset ratio of privatized banks reflects the legacy of state ownership on their balance sheets even though their equity ratios become comparable to those of foreign greenfield banks.

Regarding performance measures, the most popular one used in the financial literature is return on assets (ROA). From Tables 2 and 3, ROA is significantly higher in privatized banks than in either state-owned or domestic de novo banks and lower, but not significantly so, than in foreign greenfield banks. After privatization, ROA increases dramatically from less than one-half of one percent to over one and a half percent. To investigate the profitability of privatized banks further, we take net interest margin to represent a profit rate on lending and the commission-to-income ratio to represent the profitability of fee-for-service activities. Net interest margin is higher in privatized banks than in domestic de novo private banks but it is not significantly different between privatized banks and either state-owned or foreign greenfield banks nor does it increase significantly after privatization. Somewhat surprisingly, privatized banks have the highest commission income ratio and one significantly greater than that of foreign greenfield banks; this ratio also increases significantly after privatization. The presence of a 
strategic foreign owner in most privatized banks may explain the increased focus on feefor-service business after privatization.

On the cost side, privatized banks have lower cost ratios than state-owned banks but higher ratios than foreign greenfield banks; although the cost ratio drops by about $20 \%$ after privatization, this decrease is not statistically significant at the $5 \%$ level. To probe cost management further, we consider the non-interest expenditure ratio. Privatized banks are outperformed again by foreign greenfield banks but there are no significant differences with other types. After privatization, this ratio increases although not significantly perhaps indicating the need to incur expenses to modernize and upgrade technology.

Turning to the intermediation measures, privatized banks have significantly lower loan-to-asset ratios and significantly higher deposit-to-assets ratios than foreign greenfield banks. No other differences are statistically significant. Hence, privatized banks retain their comparative advantage in collecting primary deposits. ${ }^{9}$ However, despite having a smaller domestic deposit base, foreign greenfield banks are more aggressive than privatized banks in lending to domestic firms. Overall, our results indicate that privatization improves the financial and business situation of banks in these transition countries, making them comparable to foreign greenfield banks in some respects, but it has no statistically discernible impact on intermediation. Financially speaking, privatization matters in terms of increased profitability, more fee-for-service income, and, to a lesser extent, improved cost management.

\footnotetext{
9 The measure of deposits does not differentiate between primary, i.e., household deposits, and commercial deposits. Since commercial deposits are strongly positively correlated with business loans, we infer that privatized banks are still the major collectors of primary deposits in these countries.
} 


\section{Efficiency Estimates and Regression Results}

Although the accounting data are informative, we focus on efficiency measures to investigate the impact of ownership and privatization on bank performance. Berger, DeYoung, Genay and Udell (2000) review the literature on applying stochastic frontier analysis (SFA) to estimate bank efficiency. Bonin, Hasan, and Wachtel (2003) use this approach to examine the efficiency of banks in transition economies. In this paper, we use similar frontier specifications so that we provide only a brief summary of the salient features.

The model estimated for cost efficiency is given by:

$$
Y_{i t}=f\left(X_{i t}, P_{i t}, Z_{i t}\right)+v_{i t}+u_{i t}
$$

where $\mathrm{Y}$ represents total costs that are a function of various outputs, $\mathrm{X}$, the price of inputs, $\mathrm{P}$, and fixed effects for years and countries, $\mathrm{Z}$. As is common in the efficiency literature, we use a translog specification for the function with standard symmetry and homogeneity assumptions. The random disturbance term has two components; $\mathrm{v}_{\text {it }}$ represents measurement error and other uncontrollable factors, while $\mathrm{u}_{\mathrm{it}}$ represents technical and allocative inefficiency. The frontier approach maintains that managerial or controllable inefficiencies, i.e., $\mathrm{u}_{\mathrm{it}}$, increase costs above the frontier or best-practice levels that are subject to random fluctuations, i.e., $v_{i t .}$ We use a similar specification for the profit function except that $Y$ is total profits and the disturbance becomes $v_{i t}-u_{i t}$ because managerial inefficiency reduces profits below the frontier or best practice level.

The $\mathrm{v}_{\mathrm{it}}$ terms are assumed to be identically distributed as normal variates with zero mean and variance equal to $\sigma_{v}^{2}$. The $\mathrm{u}_{\mathrm{it}}$ terms are nonnegative random variables distributed normally but truncated below zero. We assume that the $\mathrm{u}_{\mathrm{it}}$ terms are 
distributed independently but not identically. Hence, for the $\mathrm{i}-$ th bank in year $\mathrm{t}$, technical inefficiency, $\mathrm{u}_{\mathrm{it}}$, is assumed to follow a half normal distribution with a non-constant variance, i.e., $\mathrm{N}\left(\mu, \sigma_{\mathrm{u}}^{2} \mathrm{it}\right)$. Because structural conditions in the banking sector and general macroeconomic conditions may generate differences in banking efficiency from country to country and over time, we include both country effects and time effects in the estimation of the frontier. Specifically, the year and country effects appear in the cost and profit functions directly and as determinants of the variance, i.e., $\sigma_{\mathrm{u}}^{2} \mathrm{it}=\mathrm{Z}_{\mathrm{it}} \delta$.

Total costs are the sum of interest and non-interest costs. The output variables are total deposits, total loans, total liquid assets and investments other than loans and liquid assets. The input prices are the price of capital, measured by the ratio of non-interest expenses to total fixed assets, and the price of funds, measured by the ratio of interest expenses to total deposits. Total profit is measured by net profit earned by the bank. The output variables and costs or profits are normalized by total loans and the input variable is the ratio of the price of capital to the price of funds. Thus, the specification assumes homogeneity with respect to prices and constant returns to scale. Following the literature, we add a constant amount to profit for all banks to avoid having negative net profits for any bank observation so that we may take logarithms of all profit function variables. We also estimated frontiers with alternative measures of cost and profit. The cost frontier for non-interest expenditure is virtually identical to the total cost frontier and is not discussed. The profit function using commission income is included in the ownership regressions below. The stochastic frontiers are estimated with the LIMDEP Version 8 developed by William Greene. ${ }^{10}$

${ }^{10}$ Econometric Software, Inc. (www.limdep.com). 
Summary statistics for estimates of the stochastic frontiers are given in Appendix B. These statistics are the ratio of the standard deviation of the inefficiency component of the disturbance to the random component $\left(\sigma_{u} / \sigma_{v}\right)$, the standard deviation of the composite disturbance $(\sigma)$, and the proportion of the variance in the overall disturbance that is due to inefficiency, $\lambda=\sigma_{u}{ }^{2} / \sigma^{2}$. As Appendix B indicates, most of the variation in the disturbance from best practice is due to technical inefficiency rather than random error. Since the cost and profit frontiers are translog functions, efficiency is defined as $\mathrm{e}^{-\mathrm{u}}$, where $\mathrm{u}$ is the estimated inefficiency. Hence, efficiency is always positive and it is equal to one for the best-practice or zero-inefficient bank. Individual bank efficiency is measured relative to best practice; the means and standard deviations of cost and profit efficiency are reported in Appendix B.

To investigate the impact of privatization on bank efficiency, we take the efficiency scores for each bank observation as the dependent variable in second-stage regressions having dummy variables for bank type as explanatory variables. The regression coefficients are shown in Table 4; the omitted ownership category is domestic de novo private banks. All of the regressions include dummy variables to account for country and year fixed effects, although the coefficients of these variables are not reported. Because bank privatizations in these six countries usually involve selling a state-owned bank to a strategic foreign owner, we include a dummy variable to test for the incremental impact of strategic foreign ownership. ${ }^{11}$ The dependent variables for the four regressions in Table 4 are cost and profit efficiency, an alternative measure of profit

\footnotetext{
${ }^{11}$ In $74 \%$ of all privatized-bank observations, a strategic foreign owner is present. If the observations for the Czech voucher-privatized banks are excluded, this percentage is even higher.
} 
efficiency, i.e., commission income efficiency, and a performance measure, i.e., ROA, for comparison.

Taking ROA first, ownership type explains very little of the overall variation in this financial performance measure. ${ }^{12}$ Foreign greenfield banks $(\mathrm{C} 1)$ and privatized banks (C4) have significantly higher ROAs than domestic private banks, by $2 \%$ and $1.6 \%$ on average respectively, but the presence of a strategic foreign owner (S) has no additional impact on ROA. In the final two rows of Table 4, we include the p-values for tests of differences between privatized banks (C4) and state-owned banks (C3) and between privatized banks having a strategic foreign owner $(\mathrm{C} 4+\mathrm{S})$ and state-owned banks. In both cases, privatized banks have significantly higher ROAs than their stateowned counterparts. This analysis confirms our earlier means tests indicating that privatized banks have higher earnings than state-owned banks in these transition countries.

Turning to the efficiency regressions, we find that these regressions explain a substantial percentage of the variation in efficiency. ${ }^{13}$ Foreign greenfield banks are significantly more cost and profit efficient and state-owned banks are significantly less cost and profit efficient than domestic private banks. Although privatized banks are significantly less profit efficient than domestic private banks, the presence of a foreign owner improves the profit efficiency of a bank significantly. No significant differences are found between privatized banks and domestic private banks regarding cost efficiency. Other comparisons relevant to the impact of privatization are shown by the hypothesis

\footnotetext{
${ }^{12}$ Much of the explained variation is due to country and year fixed effects that are not reported in the table. Regressions using other performance measures, which we do not report, exhibit even weaker explanatory power.

${ }^{13}$ The coefficient of variation for ROA is 2.9 while it is 0.5 or less for the three efficiency measures.
} 
tests in the final two rows of the table. Specifically, all privatized banks and privatized banks having a strategic foreign owner are significantly more cost efficient than stateowned banks. When all privatized banks are considered, no significant difference in profit efficiency relative to state-owned banks is found. However, the presence of a strategic foreign owner yields significantly higher profit efficiency. Hence, attracting a strategic foreign owner in the privatization process improves both profit and cost efficiency.

The regression using an efficiency measure based on commission income confirms our earlier means tests. Foreign greenfield banks are significantly less efficient than domestic private banks in fee-for-service activities even though the literature suggests that these banks were involved in targeting this profitable business in the transition economies. Moreover, all privatized banks are significantly more efficient at attracting fee-for-service business than are state-owned banks, although the coefficient measuring the incremental impact of a strategic foreign owner is not significant. Taken together, our results suggest that domestic private banks, either de novo or privatized, have a local comparative advantage in generating fee-for-service income and that banks focus more on, and become more efficient at, this activity after privatization.

In summary, the ownership regressions indicate that, compared with other bank types, foreign greenfield banks are the most efficient, except in generating fee-for-service business, and that state-owned banks are the least efficient. In addition, we find evidence that having a strategic foreign owner matters to bank efficiency after privatization. To investigate directly the impact of privatization, we divide the state-owned category into two groups: banks that are always state-owned in our sample (C30) and observations 
representing the state-owned pre-privatization histories of banks that are privatized within the sample period (C31). In addition, we divide the privatized category into three groups: banks that are always privatized in our sample excluding voucher privatized banks (C40), denoted early-privatized banks, observations representing the post-privatization experiences of banks that are privatized during the sample time period (C41), denoted later-privatized banks, and observations representing the voucher experiences of the three Czech banks (C42), denoted voucher-privatized banks. ${ }^{14}$

The impact of privatization on cost and profit efficiency is shown in the regressions in Table 5; country and year dummies are included but their coefficients are not reported. The coefficients for foreign greenfield banks change very little in magnitude from Table 4; they remain positive and highly significant as expected. State-owned banks that were not privatized during the sample period (C30) remain significantly less efficient than domestic private banks by both measures. Although later-privatized banks are also less cost efficient than domestic private banks during their state-owned years, the statistical significance of this difference is lower than it is for banks that remain stateowned throughout the sample period. No other coefficients are significant in the cost efficiency regression; in particular, having a strategic foreign owner does not lead to an increase in cost efficiency for privatized banks.

The $\mathrm{p}$-values for additional hypothesis tests provide some evidence that the timing of privatization matters to cost efficiency. First, early-privatized banks (C40) are significantly more cost efficient than banks that remain state-owned throughout the sample (C30). Second, early-privatized banks (C40) are significantly more cost efficient

\footnotetext{
${ }^{14}$ In our sample, we have four observations that pertain to years in which the Czech banks were privatized to strategic foreign investors. These observations are included in $\mathrm{C} 41$ not $\mathrm{C} 42$ so that $\mathrm{C} 42$ contains only the voucher experiences of these three banks.
} 
relative to the pre-privatization histories of banks that are privatized in the sample (C31). In addition, a comparison of later-privatized banks (C41) with their state-owned prehistories (C31) does not yield significant improvements in cost efficiency even when the incremental effect of a strategic owner is added $(\mathrm{C} 41+\mathrm{S})$. Finally, early-privatized banks (C40) are significantly more cost efficient than later-privatized banks (C41), indicating that the timing of privatization is important. Our results suggest that achieving the full impact of privatization on cost efficiency may take some time. ${ }^{15}$

These timing results are confirmed in the profit regression; in addition, the importance of the method of privatization is shown. First, voucher privatization does not compare with private ownership; voucher-privatized banks are significantly less profit efficient than domestic private banks. Second, voucher privatization does not lead to any improvement in profit efficiency; the comparison of voucher-privatized banks (C42) with the state-owned pre-privatization histories of privatized banks (C31) indicates no significant difference. Third, the comparison of voucher-privatized banks with earlyprivatized banks (C40) indicates that voucher-privatized banks are significantly less profit efficient than their counterparts that are privatized by other methods. Finally, laterprivatized banks that attract a strategic foreign owner $(\mathrm{C} 41+\mathrm{S})$ are significantly more profit-efficient than voucher-privatized banks. Hence, we find no evidence of any significant improvement in efficiency attributable to voucher privatization. ${ }^{16}$

Finally, the positive impact on profit efficiency of having a strategic foreign owner, which we find in the ownership regression, is confirmed in the privatization

\footnotetext{
${ }^{15}$ We tested for selection effects in the privatization process between banks that remain state-owned throughout the sample ( $\mathrm{C} 30)$ and the pre-privatization histories of later-privatized banks $(\mathrm{C} 31)$. No significant differences between these coefficients are found in either the cost or the profit regression. ${ }^{16}$ Similar comparisons of voucher-privatized banks with other bank types yield no significant differences in the cost efficiency regression.
} 
regression. The coefficient measuring the incremental effect of a strategic foreign owner is positive and significant at the $5 \%$ level in the profit regression. Moreover, the importance of attracting a strategic foreign owner is evident from the comparison between post-privatization experiences and pre-privatization histories. Comparing all later-privatized banks (C41) to their pre-privatization histories (C31) yields no significant difference in profit efficiency. However, when the incremental effect of a strategic foreign owner is included $(\mathrm{C} 41+\mathrm{S})$, the difference is significant at about the $6 \%$ level. Hence, we find evidence that attracting a strategic foreign owner in the privatization process increases a bank's profit efficiency.

In conclusion, the differences in the hypothesis tests using cost and profit efficiency measures suggest that, although banks sold to foreign owners are not more cost-efficient immediately after privatization, they do manage revenues more efficiently. The means test in Table 3 and the ownership regression in Table 4 indicate that banks pursue more fee-for-service business and do so more successfully after privatization. Taken together, these results suggest that privatized banks with strategic foreign owners redirect their attention to this profitable business. However, generating commission income requires an upgrading of both technology and human capital, which may have adverse effects on the cost side of the ledger for privatized banks and explain the insignificant findings for cost efficiency. Moreover, the robust result that earlyprivatized banks are more efficient than later-privatized banks suggests that more time may be needed to achieve the full benefits of bank privatization in transition countries. Finally, our findings indicate that voucher privatization does not lead to any increase in bank efficiency while attracting a strategic foreign investor results in higher profit 
efficiency. Hence, we conclude that both the method and the timing of privatization matter to bank efficiency.

\section{Conclusion}

Our empirical analysis confirms the propositions in the literature that government ownership of banks is inefficient and that the entry of foreign banks, which are the most efficient of all bank types, improves the performance of banking sectors in transition countries. The strategy of privatizing large state-owned banks by selling them to strategic foreign investors after recapitalization and cleaning the balance sheets, espoused by the policy literature for small, open transition countries, is supported by our empirical findings. In terms of equity and earnings, privatized banks resemble foreign greenfield banks although they have higher loan loss provisions and more liquid portfolios. In contrast to the conjecture in the literature that foreign banks engage in cream skimming, we find that domestic banks, both privatized and de novo, are more successful in pursuing fee-for-service business than are foreign banks. Although privatized banks retain their inherited ability to collect primary deposits, they make fewer loans relative to assets than do foreign banks and focus more on commission income after privatization.

Disappointingly, we find no evidence that these newly privatized banks are contributing to improving the effectiveness of financial intermediation in their respective countries.

Our empirical evidence indicates that the timing of privatization affects bank efficiency. Early-privatized banks are more efficient than later-privatized banks. In addition, compared to their pre-privatization histories, later-privatized banks are not more efficient. Although this might indicate that the better banks were privatized first, we find 
no statistically significance evidence that the state-owned banks remaining to be privatized are less efficient than were the privatized banks when they were state owned. Because we find no evidence of a selection effect, we attribute the above efficiency differences to a lag in achieving the full benefits of privatization. We do find that banks having a strategic foreign owner are more profit, but not cost, efficient after privatization. Taking into account the change in business strategy of focusing more on commission income after privatization, we infer that privatized banks incur increased cost to upgrade their technology and human capital to compete successfully for this profitable fee-forservice business but that this investment affects adversely current cost efficiency.

The method of privatization also matters. We find no evidence of any improvements from voucher privatization; for example, early-privatized banks are significantly more profit efficient than voucher-privatized banks during a comparable time period. We find evidence to support the prescribed policy of attracting a strategic foreign owner in the privatization process. Later-privatized banks are not more efficient until the impact of a strategic foreign owner is considered. In addition, banks having a strategic foreign owner are more profit efficient after privatization but such comparisons for all later-privatized banks do not yield this result. Finally, as a cautionary note for further research, our empirical results indicate that financial performance measures are not sufficient to detect the impact of bank privatization in transition countries. 


\section{REFERENCES}

Berger, Allen N., DeYoung, Robert, Genay, Hesna, and Udell, Gregory F., “Globalization of Financial Institutions: Evidence from Cross-Border Banking Performance,” Brookings-Wharton Papers on Financial Services, Vol. 3, 2000.

Bonin, John P., Mizsei, Kálmán, Székely, István and Wachtel, Paul, Banking in Transition Economies: Developing Market Oriented Banking Sectors in Eastern Europe, Edward Elgar Publishing Limited (Cheltenham, U.K.), 1998.

Bonin, John P., Hasan, Iftekhar, and Wachtel, Paul, "Bank Performance, Efficiency and Ownership in Transition Countries," Paper presented at the Ninth Dubrovnik Economic Conference, sponsored by the Bank of Croatia, June 26-28, 2003.

Buch, Claudia M., "Is Foreign Control a Panacea? - On Governance and Restructuring of Commercial Banks in Transition Economies," Kiel Institute of World Economics, April 2000.

Clarke, George and Cull, Robert, "Why Privatize? The Case of Argentina’s Public Provincial Banks,” World Development 27: 867-888, 1999.

Clarke, George and Cull, Robert, "Getting to Yes: Privatizing Banks in Argentina," World Bank, Washington, DC. 2000.

Claessens, Stijn, Demirgüc-Kunt, Asli, and Huizinga, Harry, "How Does Foreign Entry Affect the Domestic Banking Market?” Journal of Banking and Finance, 25: 891$911,2001$.

Crystal, Jennifer S, Dages, B Gerard, and Goldberg, Linda S. "Does Foreign Ownership Contribute to Sounder Banks? The Latin American Experience" in Litan, Robert E., Masson, Paul, and Pomerleano, Michael, eds., Open doors: Foreign 
participation in financial systems in developing countries, Brookings Institution Press (Washington, D.C.) 217-66, 2001

Drakos, Konstantinos. "Has the Reform in Transition Banking Delivered?: An Interest Margin Analysis," University of Essex, 2002.

Fries, Steven, Neven, Damien, and Seabright, Paul, "Bank Performance in Transition Economies," EBRD, June 2002.

Fries, Steven and Taci, Anita, "Cost Efficiency of banks in transition: Evidence from 289 banks in 15 post-communist countries," Paper presented at the Ninth Dubrovnik Economic Conference, sponsored by the Bank of Croatia, June 26-28, 2003.

Hasan, Iftekhar and Marton, K., "Banking in Transition Economy: Hungarian Evidence," Journal of Banking and Finance 27: 2249-2271, 2003.

La Porta, Rafael, Lopez-De-Silanes, Florencio, and Shleifer, Andrei, "Government Ownership of Banks," Journal of Finance 57: 265-302, February 2002.

Nikiel, Ewa M. and Opiela, Timothy P, “Customer Type and Bank Efficiency in Poland: Implications for Emerging Market Banking," Contemporary Economic Policy 20: $55-71,2002$.

Verbrugge, James, Owens, Wanda, and Megginson, William, "State Ownership and the Financial Performance of Privatized Banks: An Empirical Analysis," Conference Proceedings of a Policy Research Workshop Held at the World Bank, March 1516, 1999. Dallas: Federal Research Bank of Dallas, 2000. 
Table 1

Distribution of Observations across Bank Types

\begin{tabular}{|l|l|l|l|l|l|l|}
\hline & $\begin{array}{l}\text { Foreign } \\
\text { Greenfield } \\
(1)\end{array}$ & $\begin{array}{l}\text { Domestic } \\
\text { De novo } \\
(2)\end{array}$ & $\begin{array}{l}\text { State } \\
\text { Owned } \\
(3)\end{array}$ & $\begin{array}{l}\text { Privatized } \\
(4)\end{array}$ & TOTAL & $\begin{array}{l}\text { Strategic } \\
\text { Owner }\end{array}$ \\
\hline Bulgaria & 15 & 0 & 37 & 16 & $\mathbf{6 8}$ & $19 \%$ \\
& $(22.1)$ & $(0)$ & $(54.4)$ & $(23.5)$ & $\mathbf{( 1 5 \% )}$ & \\
\hline Czech & 22 & 9 & 6 & 28 & $\mathbf{6 5}$ & $18 \%$ \\
Rep & $(33.8)$ & $(13.8)$ & $(9.2)$ & $(43.1)$ & $\mathbf{( 1 4 . 4 \% )}$ & \\
\hline Croatia & 22 & 38 & 11 & 7 & $\mathbf{7 8}$ & $14 \%$ \\
& $(28.2)$ & $(48.7)$ & $(14.1)$ & $(9.0)$ & $\mathbf{( 1 7 . 3 \% )}$ & \\
\hline Hungary & 28 & 4 & 13 & 39 & $\mathbf{8 4}$ & $33 \%$ \\
& $(33.3)$ & $(4.8)$ & $(15.5)$ & $(46.4)$ & $\mathbf{( 1 8 . 6 \% )}$ & \\
\hline Poland & 8 & 16 & 46 & 45 & $\mathbf{1 1 5}$ & $31 \%$ \\
& $(7.0)$ & $(13.9)$ & $(40.0)$ & $(39.1)$ & $\mathbf{( 2 5 . 5 \% )}$ & \\
\hline Romania & 15 & 8 & 12 & 6 & $\mathbf{4 1}$ & $7 \%$ \\
& $(36.6)$ & $(19.5)$ & $(29.3)$ & $(14.6)$ & $\mathbf{( 9 . 1 \% )}$ & \\
\hline TOTAL & $\mathbf{1 1 0}$ & $\mathbf{7 5}$ & $\mathbf{1 2 5}$ & $\mathbf{1 4 1}$ & $\mathbf{4 5 1}$ & $23 \%$ \\
& $\mathbf{2 4 . 4 \%}$ & $\mathbf{1 6 . 6 \%}$ & $\mathbf{2 7 . 7 \%}$ & $\mathbf{3 1 . 3 \%}$ & $\mathbf{1 0 0 . 0 \%}$ & \\
\hline
\end{tabular}

Notes

(i) Entries are numbers of bank observations.

(ii) The percentage distribution by bank type within each country is in parentheses.

(iii) The column labeled TOTAL shows the number of observations in each country and the percentage distribution.

(iv) The row labeled TOTAL shows the number of observations by bank type and the percentage distribution.

(v) For strategic owner, the number shown is the percentage of all bank observations in the row.

\begin{tabular}{|c|c|c|c|c|c|c|c|c|c|}
\hline & 1994 & 1995 & 1996 & 1997 & 1998 & 1999 & 2000 & 2001 & 2002 \\
\hline Number & 47 & 55 & 55 & 54 & 59 & 59 & 59 & 54 & 9 \\
\hline Number & 6 & 9 & 11 & 16 & 19 & 24 & 27 & 25 & 4 \\
\hline $\begin{array}{l}\text { Privatized } \\
\text { and } \%\end{array}$ & $13 \%$ & $16 \%$ & $20 \%$ & $30 \%$ & $32 \%$ & $41 \%$ & $46 \%$ & $46 \%$ & $44 \%$ \\
\hline
\end{tabular}


Table 2

Bank Performance and Characteristics by Bank Type

\begin{tabular}{|c|c|c|c|c|c|c|c|}
\hline & $\begin{array}{c}\text { Foreign } \\
\text { Greenfield }\end{array}$ & $\begin{array}{l}\text { Domestic } \\
\text { De Novo }\end{array}$ & $\begin{array}{c}\text { State } \\
\text { Owned }\end{array}$ & Privatized & TOTAL & \multicolumn{2}{|c|}{$\begin{array}{c}\text { Banks Privatized in } \\
\text { Sample }\end{array}$} \\
\cline { 5 - 8 } & & & & & & Pre & Post \\
\hline $\begin{array}{c}\text { Return on } \\
\text { Assets }\end{array}$ & 0.0224 & 0.0051 & 0.0042 & 0.0176 & 0.0133 & 0.0047 & 0.0158 \\
\hline $\begin{array}{c}\text { Commission } \\
\text { income ratio }\end{array}$ & 0.014 & 0.0164 & 0.0130 & 0.0186 & 0.0155 & 0.0145 & 0.0204 \\
\hline $\begin{array}{c}\text { Net interest } \\
\text { margin ratio }\end{array}$ & 0.0417 & 0.0375 & 0.0424 & 0.0439 & 0.0422 & 0.0388 & 0.0449 \\
\hline Cost ratio & 0.1005 & 0.1434 & 0.1862 & 0.1302 & 0.1402 & 0.1631 & 0.1331 \\
\hline $\begin{array}{c}\text { Non interest } \\
\text { expenditure } \\
\text { ratio }\end{array}$ & 0.0446 & 0.0713 & 0.0754 & 0.0649 & 0.0652 & 0.0619 & 0.0686 \\
\hline Loan ratio & 0.4801 & 0.3945 & 0.3734 & 0.3797 & 0.4038 & 0.3745 & 0.3526 \\
\hline Deposit ratio & 0.7542 & 0.7583 & 0.7850 & 0.7769 & 0.7690 & 0.7738 & 0.7754 \\
\hline $\begin{array}{c}\text { Liquid asset } \\
\text { ratio }\end{array}$ & 0.4378 & 0.4340 & 0.4932 & 0.4924 & 0.4707 & 0.4924 & 0.5185 \\
\hline Equity ratio & 0.1171 & 0.1009 & 0.0729 & 0.1122 & 0.1041 & 0.0855 & 0.1187 \\
\hline $\begin{array}{c}\text { Loan loss } \\
\text { provision } \\
\text { ratio }\end{array}$ & 0.0083 & 0.0171 & 0.0177 & 0.0133 & 0.0142 & 0.0135 & 0.0103 \\
\hline $\begin{array}{c}\text { Assets (000\$) } \\
\text { Not adjusted }\end{array}$ & 813,024 & $1,606,922$ & $3,036,874$ & $4,742,269$ & $2,798,652$ & $2,501,847$ & $4,073,382$ \\
\hline
\end{tabular}

Notes

(i) The total sample size is 451 , although not all data are available for every variable.

(ii) All variables, except return on assets and assets, are ratios to total assets.

(iii) Each entry, except assets, is adjusted to remove the fixed country and year effects.

* These columns include observations for banks that were privatized in our sample only; there are 78 pre-privatization histories and 83 post-privatization bank experiences. However, observations for the second privatizations of the Czech voucher privatized banks are not included. 
Table 3

Significance of Differences in Bank Performance and Characteristics

\begin{tabular}{|c|c|c|c|c|}
\hline & \multicolumn{3}{|c|}{ Privatized banks less: } & \multirow{2}{*}{$\begin{array}{l}\text { Post less pre- } \\
\text { privatization }\end{array}$} \\
\hline & State owned & $\begin{array}{l}\text { Domestic De } \\
\text { Novo }\end{array}$ & $\begin{array}{l}\text { Foreign } \\
\text { Greenfield }\end{array}$ & \\
\hline Return on Assets & 2.58 & 2.92 & -1.47 & 2.12 \\
\hline $\begin{array}{l}\text { Commission income } \\
\text { ratio }\end{array}$ & 5.18 & 1.68 & 4.29 & 3.73 \\
\hline $\begin{array}{l}\text { Net interest margin } \\
\text { ratio }\end{array}$ & 0.39 & 2.95 & 1.12 & 1.57 \\
\hline Cost ratio & -3.68 & -1.48 & 4.76 & -1.75 \\
\hline $\begin{array}{c}\text { Non interest } \\
\text { expenditure ratio }\end{array}$ & -1.06 & -0.86 & 4.97 & 0.63 \\
\hline Loan ratio & 0.38 & -0.84 & -5.59 & -1.05 \\
\hline Deposit ratio & -0.81 & 1.41 & 1.97 & 0.11 \\
\hline Liquid asset ratio & -0.04 & 2.76 & 2.93 & 1.09 \\
\hline Equity ratio & 5.17 & 2.14 & -0.25 & 3.37 \\
\hline $\begin{array}{c}\text { Loan loss provision } \\
\text { ratio }\end{array}$ & -0.73 & -0.78 & 2.59 & -0.50 \\
\hline $\begin{array}{c}\text { Assets } \\
\text { (Not adjusted) }\end{array}$ & 3.25 & 7.26 & 9.81 & 2.65 \\
\hline
\end{tabular}

Notes (in addition to those to Table 2)

(i) The entries are signed t-statistics for the significance of the difference specified.

(ii) Bold entries are significant at approximately the 5\% level or better. 
Table 4

Ownership regressions

\begin{tabular}{|c|c|c|c|c|c|}
\hline & & $\begin{array}{l}\text { Cost } \\
\text { efficiency }\end{array}$ & $\begin{array}{l}\text { Profit } \\
\text { efficiency }\end{array}$ & $\begin{array}{l}\text { Commission } \\
\text { income } \\
\text { efficiency }\end{array}$ & $\begin{array}{l}\text { Return on } \\
\text { assets }\end{array}$ \\
\hline Constant & & $\begin{array}{l}0.762^{*} \\
(.026)\end{array}$ & $\begin{array}{l}0.265^{*} \\
(0.039)\end{array}$ & $\begin{array}{l}0.835^{*} \\
(0.024)\end{array}$ & $\begin{array}{l}-0.004 \\
(0.008)\end{array}$ \\
\hline Foreign Greenfield & $\mathrm{C} 1$ & $\begin{array}{l}0.070 * \\
(0.019)\end{array}$ & $\begin{array}{l}0.170 * \\
(0.029)\end{array}$ & $\begin{array}{l}-0.051 * \\
(0.018)\end{array}$ & $\begin{array}{l}0.020 * \\
(0.006)\end{array}$ \\
\hline State owned & C3 & $\begin{array}{l}-0.061 * \\
(0.020)\end{array}$ & $\begin{array}{l}-0.153^{*} \\
(0.029)\end{array}$ & $\begin{array}{l}-0.038 \# \\
(0.018)\end{array}$ & $\begin{array}{l}0.000 \\
(0.006)\end{array}$ \\
\hline Privatized & $\mathrm{C} 4$ & $\begin{array}{l}-0.006 \\
(0.022)\end{array}$ & $\begin{array}{l}-0.172 * \\
(0.032)\end{array}$ & $\begin{array}{l}0.038 \\
(0.020)\end{array}$ & $\begin{array}{l}0.016^{*} \\
(0.007)\end{array}$ \\
\hline Strategic owner & $\mathrm{S}$ & $\begin{array}{l}0.016 \\
(0.021)\end{array}$ & $\begin{array}{l}0.123^{*} \\
(0.032)\end{array}$ & $\begin{array}{l}-0.035 \\
(0.020)\end{array}$ & $\begin{array}{l}0.000 \\
(0.007)\end{array}$ \\
\hline Adjusted $\mathrm{R}^{2}$ & & .709 & .441 & .712 & .075 \\
\hline \multicolumn{6}{|c|}{ HYPOTHESIS TESTS } \\
\hline $\begin{array}{l}\text { Privatized vs. } \\
\text { State owned }\end{array}$ & $\begin{array}{l}\mathrm{H}_{0}: \\
\mathrm{C} 4=\mathrm{C} 3\end{array}$ & .0081 & .5691 & .0001 & .0135 \\
\hline $\begin{array}{l}\text { Privatized with } \\
\text { strategic owner vs. } \\
\text { state owned }\end{array}$ & $\begin{array}{l}\mathrm{H}_{0}: \\
\mathrm{C} 4+\mathrm{S}=\mathrm{C} 3\end{array}$ & .0024 & .0002 & .0234 & .0086 \\
\hline
\end{tabular}

Notes

(i) The omitted category is domestic private banks.

(ii) The sample size is 435 .

(iii) All regressions include fixed effects for years and countries, although these coefficients are not reported.

(iv) Standard errors are in parentheses.

(v) For regression coefficients, the symbol * indicates significance at the $1 \%$ level and the symbol \# indicates significance at the 5\% level.

(vi) For hypothesis tests, entries are the significance levels for $\chi^{2}$ tests for rejection of the null hypotheses indicated. 
Table 5

Privatization Regressions

\begin{tabular}{|l|l|l|l|}
\hline & & Cost efficiency & Profit efficiency \\
\hline Constant & & $0.762^{*}$ & $0.292^{*}$ \\
& & $(0.027)$ & $(0.041)$ \\
\hline Foreign Greenfield & $\mathrm{C} 1$ & $0.067^{*}$ & $0.163^{*}$ \\
& & $(0.019)$ & $(0.029)$ \\
\hline Always state owned & $\mathrm{C} 30$ & $-0.076^{*}$ & $-0.139^{*}$ \\
& & $(0.024)$ & $(0.035)$ \\
\hline State owned prior to \\
privatization in sample & $\mathrm{C} 31$ & $-0.049 \#$ & $-0.160^{*}$ \\
\hline Always privatized & & $(0.021)$ & $(0.032)$ \\
\hline & & 0.048 & -0.034 \\
& & $(0.030)$ & $(0.045)$ \\
\hline Privatized in sample & $\mathrm{C} 41$ & -0.022 & $-0.178^{*}$ \\
& & $(0.024)$ & $(0.036)$ \\
\hline Voucher privatization & $\mathrm{C} 42$ & -0.013 & $-0.244^{*}$ \\
& & $(0.036)$ & $(0.053)$ \\
\hline Strategic owner & $\mathrm{S}$ & 0.004 & $0.085 \#$ \\
& & $(0.023)$ & $(0.034)$ \\
\hline Adjusted $\mathrm{R}^{2}$ & & .713 & .461 \\
\hline HYPOTHESIS TESTS & & & .0001 \\
\hline Privatized early or late & $\mathrm{H}_{0}: \mathrm{C} 40=\mathrm{C} 41$ & .0036 & .0141 \\
\hline Strategic owner matters & $\mathrm{H}_{0}: \mathrm{S}=0$ & .8786 & .0012 \\
\hline Voucher differs & $\mathrm{H}_{0}: \mathrm{C} 40=\mathrm{C} 42$ & .1649 & .1156 \\
\hline & $\mathrm{H}_{0}: \mathrm{C} 31=\mathrm{C} 42$ & .3105 & .2497 \\
\hline & $\mathrm{H}_{0}: \mathrm{C} 41=\mathrm{C} 42$ & .8095 & .0063 \\
\hline & $\mathrm{H}_{0}: \mathrm{C} 41+\mathrm{S}=\mathrm{C} 42$ & .8753 & .0000 \\
\hline & $\mathrm{H}_{0}: \mathrm{C} 40+\mathrm{S}=\mathrm{C} 42$ & .1110 & .0256 \\
\hline & $\mathrm{H}_{0}: \mathrm{C} 30=\mathrm{C} 40$ & .0001 & .6246 \\
\hline Privatization matters & $\mathrm{H}_{0}: \mathrm{C} 31=\mathrm{C} 41$ & .2753 & .0000 \\
\hline & $\mathrm{H}_{0}: \mathrm{C} 30=\mathrm{C} 40+\mathrm{S}$ & .0000 & .00623 \\
\hline & $\mathrm{H}_{0}: \mathrm{C} 31=\mathrm{C} 41+\mathrm{S}$ & .1974 & \\
\hline & $\mathrm{H}_{0}: \mathrm{C} 40=\mathrm{C} 31$ & .0016 & \\
\hline & & & \\
\hline
\end{tabular}

Notes: See the notes to Table 4. 


\section{Appendix A}

\section{Ownership and Market Share of Large Banks in Six Transition Economies}

\begin{tabular}{|c|c|c|c|}
\hline & $\begin{array}{l}\text { Asset } \\
\text { Share }\end{array}$ & Ownership & $\begin{array}{l}\text { Strategic } \\
\text { owner }\end{array}$ \\
\hline Bulgaria & (2000) & & \\
\hline Bulbank & 25.4 & Privatized $10 / 00$ & $10 / 00$ \\
\hline United Bulgarian Bank (UBB) & 12.4 & Privatized 5/97 & $7 / 00$ \\
\hline $\begin{array}{l}\text { Derzhavna Spestovna Kassa } \\
\text { (DSK) }\end{array}$ & 12.1 & Privatized & $5 / 03$ \\
\hline Biochim Bank & 5.3 & Privatized & $10 / 02$ \\
\hline Bulgarian Post Bank & 5.2 & Privatized & $11 / 98$ \\
\hline SG Express Bank & 4.5 & Privatized & $11 / 99$ \\
\hline BNP-Dresdnerbank & 3.5 & Foreign Greenfield & \\
\hline Hebrosbank & 3.4 & Privatized & $3 / 00$ \\
\hline First Investment Bank & 3.3 & Foreign Greenfield & \\
\hline ING-Sofia & 2.7 & Foreign Greenfield & \\
\hline Total & 77.8 & & \\
\hline Croatia & (2000) & & \\
\hline Zagrebacka Banka & 28.9 & $\begin{array}{l}\text { Domestic Private } \\
\text { Shares sold } 12 / 99\end{array}$ & $3 / 02$ \\
\hline Privredna Banka Zagreb & 18.3 & $\begin{array}{l}\text { Domestic private; Nationalized } \\
\text { 1996; Privatized 12/99 }\end{array}$ & $12 / 99$ \\
\hline Splitska Banka & 7.1 & $\begin{array}{l}\text { Domestic private; Nationalized } \\
\text { 1996; Privatized 5/00 }\end{array}$ & $5 / 00$ \\
\hline Rijecka Banka & 7.0 & $\begin{array}{l}\text { Domestic private; Nationalized } \\
\text { 1996; Privatized 4/00 }\end{array}$ & $4 / 00$ \\
\hline Raiffeisen Bank & 4.5 & Foreign Greenfield & \\
\hline Hypo-Alde-Adria-Bank & 3.4 & Foreign Greenfield & \\
\hline Dubrovacka Banka & 2.9 & $\begin{array}{l}\text { State owned, acquired by } \\
\text { Dalmatinska } 2 / 02\end{array}$ & \\
\hline Erste\&Steiermaerkische Bank & 2.7 & Foreign Greenfield & \\
\hline Varazdinska Banka & 2.6 & $\begin{array}{l}\text { Domestic private; Acquired by } \\
\text { Zagrabacka Banka 6/00 }\end{array}$ & \\
\hline Dalmatinska Banka & 2.3 & Domestic private & $10 / 00$ \\
\hline Total & 79.7 & & \\
\hline
\end{tabular}




\begin{tabular}{|c|c|c|c|}
\hline Czech Republic & $\begin{array}{l}\text { (June } \\
\text { 2001) } \\
\end{array}$ & & \\
\hline $\begin{array}{l}\text { Ceskoslovenska Obchodni } \\
\text { Banka (CSOB) }\end{array}$ & 21.4 & $\begin{array}{l}\text { Privatized 6/99 } \\
\text { Merged with IPB 6/00 }\end{array}$ & $6 / 99$ \\
\hline $\begin{array}{l}\text { Investicni a Postovni Banka } \\
\text { (IPB) }\end{array}$ & $\begin{array}{l}\text { (part of } \\
\text { CSOB) }\end{array}$ & Voucher privatization $12 / 92$ & $3 / 98$ \\
\hline Komercni Banka & 18.4 & Voucher privatization $12 / 92$ & $6 / 01$ \\
\hline Ceska Sporitelna (CS) & 15.7 & Voucher privatization $12 / 92$ & $2 / 00$ \\
\hline $\begin{array}{l}\text { Konsolidacni banka * } \\
\text { (Not a commercial bank) }\end{array}$ & 9.0 & $\begin{array}{l}\text { State owned bank for bad debts } \\
\text { during bank restructuring. }\end{array}$ & \\
\hline GE Capital (Agrobanka) & 2.9 & $\begin{array}{l}\text { Private domestic; Nationalized } \\
\text { 1996; Privatized } 1998\end{array}$ & 1998 \\
\hline Commerzbank* & 2.7 & Foreign Greenfield & \\
\hline $\begin{array}{l}\text { Bank Austria / Credit Anstalt } \\
\text { (BACA) }\end{array}$ & 2.6 & Foreign Greenfield & \\
\hline Citibank & 2.6 & Foreign Greenfield & \\
\hline HypoVeriensbank & 2.3 & Foreign Greenfield & \\
\hline Deutsche Bank* & 2.1 & Foreign Greenfield & \\
\hline Zivnostenska Bank & 2.0 & Domestic private & $2 / 03$ \\
\hline ABN AMRO* & 2.0 & Foreign Greenfield & \\
\hline $\begin{array}{l}\text { Total (with Konsolidacni bank } \\
\text { excluded from banking sector) }\end{array}$ & 80.0 & & \\
\hline Hungary & (1999) & & \\
\hline $\begin{array}{l}\text { National Savings and } \\
\text { Commercial Bank (OTP) }\end{array}$ & 25.1 & Privatized 7/95 & \\
\hline $\begin{array}{l}\text { Hungarian Foreign Trade } \\
\text { Bank (MKB) }\end{array}$ & 9.6 & Privatized 7/94 & 1996 \\
\hline $\begin{array}{l}\text { Central-European } \\
\text { International Bank (CIB) }\end{array}$ & 8.0 & Private domestic & 1998 \\
\hline $\begin{array}{l}\text { Kereskedelmi es Hitelbank } \\
(\mathrm{K} \& \mathrm{H})\end{array}$ & 7.7 & $\begin{array}{l}\text { Privatized 7/97 } \\
\text { Merged with ABN Amro 7/01 }\end{array}$ & $7 / 01$ \\
\hline $\begin{array}{l}\text { ABN Amro / Magyar Hitel } \\
\text { Bank }\end{array}$ & 5.8 & $\begin{array}{l}\text { Privatized } 12 / 96 \\
\text { Merged with K\&H 7/01 }\end{array}$ & $12 / 96$ \\
\hline Postabank & 4.7 & $\begin{array}{l}\text { Private domestic; Nationalized } \\
1998\end{array}$ & \\
\hline Budapest Bank (BB) & 4.1 & Privatized $12 / 95$ & $12 / 95$ \\
\hline $\begin{array}{l}\text { Bank Austria - Creditanstalt } \\
\text { Hungary }\end{array}$ & 4.1 & Foreign Greenfield & \\
\hline Raiffeisen Bank & 3.7 & Foreign Greenfield & \\
\hline General Banking Trust & 3.5 & Privatized 1990 & 1996 \\
\hline Total & 76.3 & & \\
\hline
\end{tabular}




\begin{tabular}{|c|c|c|c|}
\hline Poland & (1999) & & \\
\hline $\begin{array}{l}\text { Powszechny Kasa } \\
\text { Oszczednosci-Bank } \\
\text { Panstwowy (PKO BP) } \\
\end{array}$ & 17.6 & State owned & \\
\hline $\begin{array}{l}\text { Bank Polska Kasa Opieki S.A. } \\
\text { Group (PeKaO SA) }\end{array}$ & 17.5 & Privatized 6/98 & $6 / 99$ \\
\hline $\begin{array}{l}\text { Bank Przemyslowo- } \\
\text { Handlowy+Powszechny Bank } \\
\text { Kredytowy (BPH+PBK) }\end{array}$ & 9.5 & $\begin{array}{l}\text { BPH privatized } 1 / 95 \\
\text { PBK privatized } 10 / 97 \\
\text { Merger } 12 / 01\end{array}$ & $\begin{array}{l}\text { BPH } \\
11 / 99 \\
\text { PBK } \\
10 / 97\end{array}$ \\
\hline Bank Handlowy+Citibank & 8.0 & $\begin{array}{l}\text { Privatized 6/97 } \\
\text { Merged with Citibank 2/00 }\end{array}$ & $2 / 00$ \\
\hline $\begin{array}{l}\text { Bank Inicjatyw } \\
\text { Gospdarczch+Bank Gdanski } \\
(\mathrm{BIG}+\mathrm{BG})\end{array}$ & 6.3 & $\begin{array}{l}\text { BIG Domestic private } \\
\text { BG privatized } 12 / 95 \\
\text { Merger } 9 / 98\end{array}$ & $1 / 01$ \\
\hline $\begin{array}{l}\text { Bank Slaski+ING-Barings } \\
\text { (ING) }\end{array}$ & 5.5 & $\begin{array}{l}\text { Privatised 9/93 } \\
\text { Merged with ING 4/01 }\end{array}$ & $7 / 96$ \\
\hline $\begin{array}{l}\text { Wielkopolski Bank } \\
\text { Kredytowy+ Bank Zachodni } \\
(\text { WBK + BZ) }\end{array}$ & 5.4 & $\begin{array}{l}\text { WBK privatized } 3 / 93 \\
\text { BZ privatized } 1999 \\
\text { Merger } 12 / 00\end{array}$ & $\begin{array}{l}\text { WBK } \\
4 / 97 \\
\text { BZ } 1999 \\
\end{array}$ \\
\hline $\begin{array}{l}\text { Bank Gospordarki } \\
\text { Zywnosciowej (BGZ) }\end{array}$ & 5.1 & State owned & \\
\hline Kredyt Bank & 4.3 & Private domestic & 1999 \\
\hline $\begin{array}{l}\text { Bank Rozwoju Eksportu } \\
\text { (BRE) }\end{array}$ & 4.2 & Privatized 6/92 & $10 / 00$ \\
\hline Total & 83.4 & & \\
\hline
\end{tabular}




\begin{tabular}{|l|l|l|l|}
\hline Romania & $\begin{array}{l}\text { (March } \\
\mathbf{2 0 0 2})\end{array}$ & & \\
\hline $\begin{array}{l}\text { Banca Comercială Română } \\
\text { (BCR) }\end{array}$ & 31.2 & State owned & \\
\hline $\begin{array}{l}\text { Banca Română pentru } \\
\text { Dezvoltare - Société } \\
\text { Générale }\end{array}$ & 15.7 & Privatized 3/99 & $3 / 99$ \\
\hline $\begin{array}{l}\text { Casa de Economii şi } \\
\text { Consemnațiuni }\end{array}$ & 8.6 & State owned & \\
\hline ABN Amro Bank & 5.5 & Foreign Greenfield & \\
\hline ING Bank Bucharest Branch * & 5.1 & Foreign Greenfield & \\
\hline Banc Post & 4.1 & Privatized 4/99 & $7 / 01$ \\
\hline Raiffeisen -Banca Agricolă & 3.5 & Privatized 7/01 & \\
\hline $\begin{array}{l}\text { Banca Comercială „Ion } \\
\text { Tiriac” }\end{array}$ & 3.1 & Private domestic & \\
\hline Citibank & 3.1 & Foreign Greenfield & \\
\hline ALPHA Bank & 2.7 & Foreign Greenfield & \\
\hline Total & 82.6 & & \\
\hline
\end{tabular}

Notes

(i) The symbol * indicates that the bank is not included in sample. For these foreign greeenfield banks, no data are reported in BankScope because the bank's balance sheet is consolidated with its parent. Konsolidacni Banka is excluded because it is not a commercial bank.

(ii) The PeKaO Group in Poland includes three of the original nine commercial banks hived off from the portfolio of the Central Bank. These are Pomorski Bank Kredytowy (PBKS) in Szczecin, Bank Depozytowo-Kredytowy (BDK) in Lublin, and Powszechny Bank Gospardarczy (PBG) in Lodz.

(iii) Although not effectuated in 1999, the mergers of some Polish banks, i.e., $\mathrm{BPH}+\mathrm{PBK}$, Bank Handlowy+Citibank, Bank Slaski+ING, and WBK+BZ, are considered to be merged in the table so that we add the assets of the partners in 1999 to obtain the newly merged entity's market share.

Sources: Annual reports of the National Bank of Croatia, the National Bank of Bulgaria, the National Bank of Hungary and the National Bank of Romania as well as annual reports of individual banks. In addition, data are also taken from Ceska Bankovni Asociace (Czech Republic) and Hungarian Banking Association, 2000. Data for Poland are taken from Najlepsze Banki, 2000 and Gazeta Bankowa, June 10, 2000, p.31. 


\section{Appendix B}

\section{Summary of Stochastic Frontier Estimates}

\begin{tabular}{|c|c|c|c|}
\hline & $\begin{array}{l}\text { Cost } \\
\text { efficiency }\end{array}$ & $\begin{array}{l}\text { Profit } \\
\text { efficiency }\end{array}$ & $\begin{array}{l}\text { Commission } \\
\text { income } \\
\text { efficiency }\end{array}$ \\
\hline & $(1)$ & $(2)$ & $(3)$ \\
\hline Log Likelihood & -129.3 & -531.1 & -271.2 \\
\hline$\sigma_{\mathrm{u}} / \sigma_{\mathrm{v}}$ & 2.93 & 4.59 & 1.73 \\
\hline$\sigma$ & 0.689 & 1.576 & 0.708 \\
\hline$\lambda$ & .90 & .95 & .75 \\
\hline Mean efficiency & 0.786 & 0.445 & 0.758 \\
\hline Standard deviation & 0.219 & 0.237 & 0.207 \\
\hline
\end{tabular}

Notes

(i) See the text for an explanation of the frontier specification.

(ii) Frontiers were estimated with the 431 bank observations that contain all the data needed for the estimation. Missing information reduced our sample size by only 20 observations from the sample used in the means tests.

(iii) $\sigma_{\mathrm{u}}$ and $\sigma_{\mathrm{v}}$ are the standard deviations of the composite of the inefficiency and random components of the disturbance, respectively.

(iv) $\sigma$ is the standard deviation of the overall disturbance, i.e., $(u+v)$ for the cost function and (u-v) for the profit function.

(v) $\lambda=\sigma_{\mathrm{u}}{ }^{2} / \sigma^{2}$ is the proportion of the variance in the overall disturbance that is due to inefficiency. 